\title{
The Competitive Advantage of Small Industry Batik
}

\author{
Aam Amaningsih Jumhur ${ }^{1}$ and Melly Prabawati ${ }^{2}$ \\ 1'Department of Vocational Education Mechanical Engineering, Universitas Negeri Jakarta, \\ Indonesia \\ ${ }^{2}$ Department of Vocational Education Fashion, Universitas Negeri Jakarta, Indonesia
}

\section{Abstract}

The effect of human capital and competitive advantage has empirically resulted in varied studies with regards to industry or service sectors as the object of the study. Human capital on one side directly affects the competitive advantage in addition to giving an effect to the competitive advantage mediated by organizational culture variable on the other side. Regarding this condition, this study aims to investigate the effect of organizational culture mediation towards the correlation between human capital and competitive advantage in small industry batik Trusmi. 200 batik makers

Corresponding Author: Aam Amaningsih Jumhur aamamaningsihjumhur@unj.ac.id

Received: 11 January 2019 Accepted: 14 February 2019 Published: 25 March 2019

Publishing services provided by Knowledge E

(c) Aam Amaningsih Jumhur and Melly Prabawati. This article is distributed under the terms of the Creative Commons.

Attribution License, which permits unrestricted use and redistribution provided that the original author and source are credited.

Selection and Peer-review under the responsibility of the $3 \mathrm{rd}$ ICTVET 2018 Conference Committee.

\section{S OPEN ACCESS} located in Trusmi, Cirebon, Indonesia were selected as respondents of the study. They consisted of 131 males and 69 females dominantly age 41 to 60. Correlation and regression analysis were employed as methods of the study. It can be concluded based on the regression test on human capital and competitive advantage variables, and on the presence of organizational culture as mediator variable that there is a significant correlation between human capital and mediator variables (organizational culture), and competitive advantage variable altogether. It shows that there is no a direct effect of human capital variable toward competitive advantage variable.

Keywords: competitive advantage, human capital, organizational culture, small industry batik, intervening variable

\section{Introduction}

The existence of Small and Medium Enterprise (SMEs) in Indonesia is deemed important for some reasons. According to Beery [1], SMEs is the potential source to create employment and it can help to promote the economic growth. In addition, according to Ikuro [2], small industry is a sector that is considered to be developed and have the competitive power in which if only 5\% from all the SMEs in Indonesia can be empowered, then this industries will become a strong support for large scale industry and SMEs will be able to improve its existence in the national economy with various contributions, both macro and micro [2]. 
Batik Trusmi industry which is located in Cirebon, West Java, Indonesia is a hereditary business which has been known since the 14th century and nowadays has developed as the people's livelihood. Batik industry is a culture- and tradition-based industry in which its raw materials is available in the country. In addition, it also has cultural value and help absorbing quite a lot of labour force with owned some special skills.

The performance of batik small industry organizations depends on the level of competitive advantage. there are several factors that influence the increase in competitiveness including human capital. Human capital is an organizational asset that refers to the basic competencies of workers in the organization such as expertise, knowledge, experience, potential and capacity. The development of human capital in organizations is the main challenge of leaders to create organizational competitive advantage. The efforts of organizations to have a skilled and knowledgeable workforce are the strengths of the organization compared to their competitors [3]. Workers in small batik industries that have high creativity that produce good batik motif designs are interpreted as quality and innovative human capital. Innovation is also a factor that influences competitive advantage according to Hadiyati [4].

According to Porter [5] competitive advantage exists when companies are able to provide the same benefits as competitors, Stevenson [6] defines competitive advantage as a company of effectiveness in using organizational resources to satisfy customers' demands when compared to competitors. Barney [7] defines competitive advantage in two types, namely competitive advantage is temporary and sustainable. Developing sustainable competitive advantage, the company must have superior resources and capabilities. There are four attributes sustainable competitive advantage [8-10]: product uniqueness, competitive prices, rare or rare, not easily replicated.

The higher competition in the national batik industry has encouraged small industry like Batik Trusmi to find appropriate strategy that can be used to improve its competitive advantage against batik products from other regions. There are many efforts that have been made to improve the resources and knowledge of the human resources which are expected to be able to help improving the human resources' quality as the human capital which is supported by an organizational culture to increase the competitive advantage of small industries. The aim of this study is to determine how the organizational culture variables intervene in the relationship between the human capital variables with competitive advantage, so that the entrepreneur of small batik industry would be able to formulate and choose the right strategy to win the competition by managing its human capital well. 


\section{Method}

This study was an empirical quantitative study. The subjects of this study would be consisted of the actors on small industry in Batik Trusmi centre. This study used primary data in the form of questionnaires distributed to 200 respondents using purposive random sampling study. The data obtained from the questionnaire were analysed using Classic Assumption Test, Multiple Linear Regression and hypothesis testing ( $f$-test and $t$-test) with significance level of $\alpha=5 \%$ by using SPSS version 21. Three statistical analysis instruments were employed in this study, they are (1) correlation analysis, (2) simple linear regression analysis, and (3) multiple linear regression. This multiple linear regression was used because it met the objective of the study that was to investigate the effect of mediation in organizational culture toward the correlation between human capital and competitive advantage in Indonesia's Trusmi Batik industry.

\subsection{Sampling data collection}

There are 416 of Small Industries in centres of Small Industries Trusmi Batik Cirebon regency, Indonesia. All the 200 respondents in this study are small batik industry entrepreneurs, contained 131 male respondents and 69 female. This study using accidental sampling as respondents sampling method is based on spontaneity factors, means anyone who accidentally meet investigators and in accordance with the characteristics, then the person can be used as a sample (respondents). By using Slovin's formula [11]. Questionnaires were distributed to 204 respondents, but only 200 questionnaires were returned.

\section{Results}

\subsection{Regression analysis of human capital and competitive advantage}

The result of regression analysis of human capital and the competitive advantage variable showed that the correlation between human capital and competitive advantage variable was 0.372 which indicated a high correlation. Reliability level of the regression model formed was 0.134 (coefficient of determination or Adjusted $R^{2}$ ). This value showed that $13.4 \%$ variation of variable data from competitive advantage variable could be explained by the human capital management variable. 
Based on ANOVA results, it was known that the value of $F$-count regression model formed was ( $F=30.557$ ). This value was significant at the significance level of less than $\alpha=5 \%$. The significance relationship between human capital variable with competitive advantage variable was indicated by the beta coefficient of human capital and competitive advantage variable which was equal to 0.372 . This value was significant at significance level of less than $\alpha=5 \%$.

Based on the results of regression testing on human capital and competitive advantage variable, it could be concluded that there was a significant correlation between the two variables. This result indicated that there was relationship between the intervening variables (organizational culture) with the competitive advantage variable.

\subsection{Regression analysis of organizational culture and competitive advantage}

The result of regression analysis of organizational culture and competitive advantage variable showed that the correlation between organizational culture and competitive advantage variable was

0.384 which indicated a fairly high correlation. Reliability level of the regression model formed was 0.143 (coefficient of determination or Adjusted $\mathrm{R}^{2}$ ). This value showed that $14.3 \%$ variation of variable data from competitive advantage variable could be explained by organizational culture variable.

Based on ANOVA results, it was known that the value of $F$-count regression model formed was $(F=32.918)$. This value was significant at the significance level of $\alpha=5 \%$. The significance relationship between organizational cultural variable with competitive advantage variable was indicated by the beta coefficient of organizational culture and competitive advantage variable which was equal to 0.384 . This value was highly significant at significance level of less than $\alpha=5 \%$.

Based on the results of regression testing on organizational culture and competitive advantage variable, it could be concluded that there was significant relationship between the two variables.

\subsection{Regression analysis of human capital and organizational culture}

The result of regression analysis of the human capital and organizational culture variable showed that the correlation between human capital and organizational culture variable 
was 0.372 which indicated a fairly high correlation. Reliability level of the regression model formed was 0.134 (coefficient of determination or Adjusted $R^{2}$ ). This value showed that $13.4 \%$ of variation of variable data from organizational culture variable could be explained by human capital management variable.

Based on ANOVA results, it was known that the value of $F$-count regression model formed was $(F=30.557)$. This value was significant at the significance level of less than $\alpha$ $=5 \%$. The significance relationship between human capital variable with organizational culture variable was indicated by the beta coefficient of human capital and competitive advantage variable which was equal to 0.372 . This value was significant at significance level of less than $\alpha=5 \%$.

Based on the results of regression testing on human capital and organizational culture variable, it could be concluded that there was a significant correlation between the two variables. This result indicated that there was relationship between the intervening variables (organizational culture) with human capital management variable.

\subsection{Regression analysis of human capital and organizational culture with competitive advantage}

The result of regression analysis of human capital and organizational culture variable with competitive advantage variable could be seen in the following tables:

TABLE 1: Summary of the human capital and organizational culture with competitive advantage.

\begin{tabular}{l|c|c|c|c|} 
Model & $\mathbf{R}$ & R-Square & $\begin{array}{c}\text { Adjusted } \\
\text { R-Square }\end{array}$ & $\begin{array}{c}\text { Std. Error of the } \\
\text { Estimate }\end{array}$ \\
\hline 1 & $0.455^{a}$ & 0.207 & 0.199 & 5.13058 \\
\hline Note: ${ }^{a}$ Predictors: (Constant), Organizational Culture, Human Capital.
\end{tabular}

Table 2 showed that the correlation between human capital and organizational culture variable with competitive advantage was 0.455 which indicated a high correlation. Reliability level of the regression model formed was 0.199 (coefficient of determination or Adjusted $\mathrm{R}^{2}$ ). This value showed that $48.7 \%$ of the variation of variable data from competitive advantage variable could be explained by human capital variable and organizational culture variable (intervening variable). The significance level of the relationships between human capital and organizational culture variable with the competitive advantages variable were shown in the ANOVA table below:

Based on Table 3 above, it could be seen that the value of $F$-count regression model formed was $(F=24.698)$. This value was significant at the significance level of less than $\alpha=5 \%$. The significance relationship between human capital and organizational culture 
TABLE 2: ANOVA results of Human Capital and Organizational Culture with Competitive Advantage.

\begin{tabular}{|c|c|c|c|c|c|c|}
\hline \multicolumn{2}{|c|}{ Model } & \multirow{2}{*}{$\begin{array}{c}\text { Sum of } \\
\text { Squares } \\
1300.226\end{array}$} & \multirow{2}{*}{$\begin{array}{l}\text { df } \\
2\end{array}$} & \multirow{2}{*}{$\begin{array}{c}\text { Mean } \\
\text { Square } \\
650.113\end{array}$} & \multirow{2}{*}{$\begin{array}{c}\text { F } \\
24.698\end{array}$} & \multirow{2}{*}{$\begin{array}{c}\text { Sig. } \\
0.000^{b}\end{array}$} \\
\hline 1 & Regression & & & & & \\
\hline & Residual & 4975.024 & 189 & 26.323 & & \\
\hline & Total & 6275.250 & 191 & & & \\
\hline
\end{tabular}

variable with competitive advantage variable could be seen in Table 4 which shown that the beta coefficient of human capital variable with presence of organizational cultureas the intervening variable-and competitive advantage variable was equal to 0.264. This value was highly significant at significance level of less than $\alpha=5 \%$.

TABLE 3: Beta coefficient of Human Capital and Organizational Culture with Competitiveness Advantages.

\begin{tabular}{l|c|c|c|}
\multicolumn{1}{l|}{ Model } & \multicolumn{2}{c}{ Unstandardized Coefficients } \\
\hline & & B & Std. Error \\
\hline & (Constant) & 44.393 & 4.232 \\
\hline Human Capital & 0.150 & 0.040 \\
\hline & Org. Culture & 0.204 & 0.050 \\
\hline
\end{tabular}

\begin{tabular}{|c|c|c|}
\hline $\begin{array}{l}\text { Standardized } \\
\text { Coefficients }\end{array}$ & $t$ & Sig. \\
\hline \multicolumn{3}{|l|}{ Beta } \\
\hline & 10.489 & 0.000 \\
\hline 0.264 & 3.767 & 0.000 \\
\hline 0.283 & 4.046 & 0.000 \\
\hline
\end{tabular}

Based on the results of regression testing on human capital variable with the competitive advantage variable and the presence of organizational culture as intervening variables it could be concluded that there was a significant relationship between the human capital and intervening variable (organizational culture) as well as with competitive advantage variable.

\section{Discussion}

Based on the results of regression testing on human capital variable with the competitive advantage variable and the presence of organizational culture as intervening variables it could be concluded that there was a significant relationship between the human capital and intervening variables (organizational culture) as well as with competitive advantage variable. This result showed that organizational culture variable was an intervening variable between human capital and competitive advantage variable in Batik Trusmi industry, Indonesia.

The analysis result showed that organizational culture variable was an intervening variable between human capital and competitive advantage variable in Batik Trusmi 
industry, Indonesia. It indicated that human capital variable indirectly affected the competitive advantage variable. Thus, the factor on Batik Trusmi Industry needed to consider the organizational culture variable in developing the competitive advantage of Batik Trusmi industry in Indonesia.

The results of this study are different from the results of a study from Florence et al.

[12] which states that organizational values have no influence on competitive advantage. This income is refuted by Abdullah et al. [13]. His research findings reveal that organizational culture has a positive and significant influence on competitive advantage. This statement is supported by the results of a study conducted by Jardon and Loureiro [14] which states that human capital can positively influence organizational performance by enabling them to understand the complexity of various business processes that are transferred and carry out satisfactory processes by following quality aspects, security and deadline. However, the impact is indirect. Human capital requires a mediator to achieve the desired performance. The results of the study indicate that this complexity must be managed together with the company's internal resources to facilitate the interaction of human resources and technology that produces core competencies [15].

Jamal and Saif [16] emphasize that human resources are the difference between success and failure, where it forms the most important resource in any organization. Chin and Sofian [17] show that human resources are resources owned by all organizations which are the key to their success and continuity. Fayoumi [18] states that human resources effectively work to improve quality and improve what makes this quality precedent, providing a competitive advantage for organizations. This is usually done when building organizations, developing human resources which are important factors in improving and developing performance levels based on quality. source and nature of competitive advantage based on Campbell's human capital [19].

Management of human capital indirectly influences competitive advantage through the culture of the batik industry organization Trusmi. The findings of this study are consistent with Mushref's [20] study which examined the role of organizational culture as a modifiable variable in the relationship between intellectual capital and business performance and organizational competitive advantage. Organizations with knowledgeable and skilled human resources and supported by the influence of organizational-oriented and work-oriented culture make the organization more profitable than its competitors. According to Bogdanowicz [21] through company profiles that have been produced through his research found that organizations that successfully develop and build positive cultures are potential organizations that have the potential to achieve competitive 
advantage. Organizations must have an organizational culture that is in harmony with worker's values and consistent with the environment in which the organization operates and has quality human resources and competencies. In Bogdanowicz's research shows that organizational culture is aligned with the strength of the organization's internal strategy, significantly increasing organizational competitiveness.

Organizations that want to achieve competitive advantage not only depend on competent human capital but must be supported by organizational culture practices that emphasize good aspects of moral ethics and value systems that encourage integration, knowledge sharing, autonomy, innovation and total employee participation. This finding is consistent with Robbin's [22] organizational culture theory, because organizational culture is able to produce competitive advantage and improve organizational performance. Individual-oriented human capital by maintaining and protecting the health of employees as indicated by good performance by employees and supported by physical endurance.

\section{Conclusion}

Human capital had a pivotal effect on the organizational culture through the human resources management since human capital was the strategic resource and also the source of competitive advantage. Elements of organizational culture cannot be ignored if the organization wants to achieve competitive advantage apart from manufacturing strategy, human capital and innovation strategies. Organizational culture that supports human capital can strengthen the competitive advantage of organizations in this case the small batik industry...

\section{References}

[1] Berry, A., E. Rodriguez, and H. Sandee. 2001. Small and Medium Enterprise Dynamics in Indonesia, Bulletin of Indonesian Economic Studies, 37(3), 363-384.

[2] Ikuro Yamamoto-JICA, 2006, Learning Technologies on SMEs in Indonesia: A Case Study of Metal and Machinery, in the DR. Zulkieflimansyah, Ph.D.

[3] Memon, et al., 2009 Dr. Muhammad Aslam Memon, Riaz Ahmed Mangi and Dr.Chandan Lal Rohra Human Capital a Source of Competitive Advantage -ldeas for Strategic Leadership Australian Journal of Basic and Applied Sciences, 3(4): 4182 4189, 2009 ISSN 1991-8178. 
[4] Ernani Hadiyati. 2011. Kreativitas dan Inovasi Berpengaruh Terhadap Kewirausahaan Usaha Kecil. Jurnal Manajemen Dan Kewirausahaan,13, 1, 8-16.

[5] Porter, M. E. 1985. The Competitive Advantage: Creating and Sustaining Superior Performance. New York: Free Press.

[6] Stevenson, W.J..2009. Operations Management, 10th Edition, McGraw Hill.

[7] Barney, J.B., \& Hesterly, W.S. (2008). Strategic Management and Competitive Advantage: Concepts and Cases. Pearson Prentice Hall Inc.

[8] Barney, J.B. 1991. Firm Resources and Sustained Competitive Advantage. Journal of Management Science, 17(1), 99-120.

[9] Collis, D.J., \& Montgomery, C.A..1995. Competing on Resources: Strategy in the1990s.Harvard Business Review, 73 (4), 118-128. (July-August).

[10] Conner, K.R., \& Prahalad, C.K. 1996. A resource-based theory of the firm: Knowledge versus opportunism. Organization Science, 7, 477-501.

[11] Sevilla, C. G. et al. 1960. Research Methods. Quezon City: Rex Printing Company

[12] Chepngeno Florence, K. Wagoki Juma, Okello Barrack. 2014. Effects of Organizational Culture o Sustainable Competitive Advantage in State Owned Corporations in Kenya: A Case of Postal Corporation of Kenya. International Journal of Science and Research (IJSR).Volume 3 Issue 10, October.

[13] Salma Abdullah, Chalid Imran Musa, Muhammad Azis3Abdullah.2010. The Effect of Organizational Culture on Entrepreneurship Characteristics and Competitive Advantage of Small and Medium Catering Enterprises in Makassar International Review of Management and Marketing International Review of Management and Marketing, ISSN: 2146-4405 2017, 7(2), 409-414.

[14] Carlos M. F-Jardon and Miguel Gonzalez-Loureiro. 2013. Human Capital as Source for Sustained Competitive Advantages in SMEs: A Core Competencies Approach. Economia. Seria Management Volume 16, Issue 2, 2013.

[15] Lahiri, S., Kedia, B. L., \& Mukherjee, D. 2012. The impact of management capability on the resource-performance linkage: Examining Indian outsourcing providers. Journal of World Business, 47(1), 145-155.

[16] Jamal, Waseef \& Saif, M. Iqbal.2011. Impact of Human Capital Management on Organizational Performance, European Journal of Economics, Finance and Administrative Sciences, No.34: 55-69.

[17] Chin, Khor Saw \& Sofian, Saudah.2011. The Impact of human capital and total quality management on corporate performance: a review, Interdisciplinary Journal of Contemporary Research in Business, Vol. 3, No. 3: 1091-1100. 
[18] Fayoumi, Ahmed Mohammed. 2010. The impact of intangible assets in achieving competitive advantage in light of the adoption of total quality management standards: a comparative study on a sample of Jordan's public and private universities, unpublished Master Thesis, Middle East University, Oman: Jordan.

[19] Benjamin Campbell. 2012. Rethinking Sustained Competitive Advantage from Human Capital All Faculty Publications Brigham Young University BYU Scholars Archive The Ohio State University Russell Coff University of Wisconsin-Madison

[20] Mushref, Abbas Mezeal. 2014. The Moderator Role of Organizational Culture between Intellectual Capital and Business Performance: An Empirical Study in Iraqi Industry. Net Journal of Social Sciences, 2, 3, 82-91.

[21] Maryla Bogdanowicz. 2014. Organizational Culture as a Source of Competitive Advantage - Case Study of a Telecommunication Company in Poland. International Journal of Contemporary Management, 13(3), 53-66.

[22] Robbins, Stephen, P. 2007. Organizational Behavior. 11th Edition. New Jersey: Pearson Prentice Hall. 